\title{
Microbial Ecology in the Era of Next Generation Sequencing
}

\section{Surajit De Mandal' ${ }^{1}$ Amrita Kumari Panda ${ }^{2}$, Satpal Singh Bisht ${ }^{2}$ and Nachimuthu Senthil Kumar ${ }^{1 *}$}

${ }^{1}$ Department of Biotechnology, Mizoram University, Aizawl-796004, Mizoram, India

${ }^{2}$ Department of Zoology, Kumaun University, Nainital-263002, Uttarakhand, India

\begin{abstract}
Microorganisms are the major part of earth's biological diversity. Due to most of the microbes being nonculturable, it is necessary to use culture independent techniques to study the uncultured microbes. Metagenomics is the molecular tool which helps to understand the genetic makeup of the wide variety of uncultivable microorganisms. Currently, Next Generation Sequencing (NGS) is one of the most advanced technologies used in metagenomics studies and different computational tools have been developed for the analysis of large metagenomic dataset. This review demonstrates the different tools used in NGS analysis and its applications in microbial ecology.
\end{abstract}

Keywords: Biological diversity; Metagenomics; Next generation sequencing

\section{Introduction}

Natural environments harbor a large number of microorganisms representing the major reservoir of undescribed biodiversity [1] and occupy diverse habitats from deep sea sediments to high up in the atmosphere [2]. But, most of the microbes are unculturable by standard techniques $[3,4]$. Thus, their ecology and functional roles are unknown and our understanding of the composition of the natural microbial world is therefore rudimentary. The reason for uncultivable nature may be the fact that they depend on other organisms for critical processes, fail to grow in vitro or have even become extinct in fossil records [5]. Some are metabolically active, even though they were unculturable in laboratory [6]. Culturing these microbes in artificial environment needs in-depth knowledge of the nutrient and growth requirements. Although some work has attempted to culture these uncultivable bacteria $[7,8]$, the technique is time consuming and laborious and therefore needs some alternative methods to study them.

DNA sequence-based methods can overcome these problems since we can isolate the genetic material directly from live or dead cells from various environmental samples, allowing a new emerging field called metagenomics. Metagenomics involves the culture independent approach to study the unculturable microorganisms directly from an environmental samples such as soil [9,10], seawater [11], ground water [12], antarctic desert soil [13] etc. In the mid-1980s, Norman Pace [14] suggested a culture-independent approach which was later named as "metagenomics" by Handelsman and first appeared in publication in 1998. This field is also called as environmental genomics, ecogenomics or community genomics. In this technique, the isolation of environmental DNA directly resulted in the isolation of a number of novel genes and was designed with several practical gains such as the discovery of new genes and gene products that would lead to agricultural innovations, medicinal chemistry and industrial processes. It can also be used to reveal diversity patterns of microorganisms, horizontal gene transfer analysis, identification of novel metabolic pathways and examining genes/operons for desirable enzyme candidates (e.g., cellulases, chitinases, lipases, antibiotics) and other natural products $[3,15,16]$.

\section{Ribosomal RNA for the identification of uncultured bacteria and its community}

Ribosomal RNA is largely used for the study of uncultured bacteria as it has several advantages. The $16 \mathrm{~S}$ gene occurs in all living organisms with the notable exception of viruses and represents more than $80 \%$ of total bacterial RNA found in every living cell and generally stable and long enough (approx. $1500 \mathrm{nt}$ ), contains independently evolving domains, i.e. variable regions. They are shorter than 23s (approx. 2300 nt) and easier to sequence. The 16S rRNA gene structure consists of interspersed conserved and variable regions which is suitable for PCR amplification and sequencing. As a molecular chronometer, these molecules have preserved their evolutionary history. Most of the studies have been carried out with 16S rRNA and has been used as a phylogenetic marker as it is present in all prokaryotes and contains different hypervariable regions separated by highly conserved gene segments. They have highly conserved portion which carries the information on early evolutionary events and more recent changes are documented within less conserved position or stretches. The degree of divergence of present day rRNA sequence gives an estimate of their phylogenetic distance. They donot have any ortholog - paralog issues or horizontal gene transfer. It is easy to PCR amplify and they have a very slow rate of mutation. The new era of metagenomics was ushered in by studies using 16S rRNA as a phylogenetic marker of microbial taxa. Focusing on a small part of the microbial genome brings down the sequencing costs dramatically [17].

It is important to choose the appropriate variable region of the 16S rRNA for microbial ecological studies mainly for biogeography, metacommunity theory or microbiome analysis. Previous studies selected the hypervariable region which can exhibit sufficient phylogenetic signals to classify at the genus level [18]. Liu et al. [19] suggested for the 250 bp region between the V2 and V3 hypervariable regions for microbial ecological studies. The use of tags of the V3 and V6 regions in 454 pyrosequencing also provides sufficient taxonomic assignments [20]. Analysis by Wang et al. [21] proved that V2 and $\mathrm{V} 4$ regions can results best taxonomic assignment at the genus level, where as for the study of microbial community complex ecosystem it is recommended to use V7-V8 region [22,23].

*Corresponding author: Nachimuthu Senthil Kumar, Department of Biotechnology, Mizoram University, Aizawl-796004, Mizoram, India, Tel: +91-9436352574; Email: nskmzu@gmail.com

Received October 13, 2015; Accepted Novmber 30, 2015; Published December 03, 2015

Citation: De Mandal S, Panda AK, Bisht SS, Kumar NS (2015) Microbial Ecology in the Era of Next Generation Sequencing. Next Generat Sequenc \& Applic S1: 001. doi:10.4172/2469-9853.S1-001

Copyright: (C) 2015 De Mandal S, et al. This is an open-access article distributed under the terms of the Creative Commons Attribution License, which permits unrestricted use, distribution, and reproduction in any medium, provided the original author and source are credited. 


\section{Analysis of metagenome using DGGE and TGGE}

Sanger sequencing (first generation sequencing) was widely used for molecular biology studies with no or minimum errors. Based on the Sanger sequencing approach, different PCR based methods have been developed to study the microbial communities. Denaturing Gradient Gel Electrophoresis (DGGE) or Terminal Restriction Fragment Length Polymorphism (T-RFLP) has been developed to analyze the uncultured microbial communities in diverse environments [24,25]. These methods allow differentiating gene molecules (in polyacrylamide gels) based on the decreased electrophoresis mobility of a partially melted double stranded DNA molecule at the level of a single base containing a linear gradient of DNA denaturants (a mixture of urea and formamide) or a linear temperature gradient. However, these techniques present several drawbacks as the dominant populations are better revealed and bands from more than one species may be hidden behind a single band resulting in underestimation of bacterial diversity. The same isolate can have different identifiable bands because multiple copies of $16 \mathrm{~S}$ rRNA gene are present in a single genome of species. The Sanger sequencing based methods present several drawbacks since it is expensive and cannot detect rare microorganisms [26,27].

\section{Next generation sequencing technology (NGS)}

NGS allows massively parallel sequencing with thousands to millions of sequences in one experiment at considerably low cost compared to Sanger method. There are no requirements of bacterial cloning of DNA fragments and electrophoresis, since NGS libraries preparation process are carried out in a cell-free system and the sequence output is directly detected. However, it produces shorter reads with a higher error rate than Sanger sequencing [28-30]. Moreover, secondary structure and thermal stability of the genome affects the efficiency of PCR amplification of the genomic fragments. There are different NGS platforms (e.g. Illumina, Pacific Biosciences, Ion Torrent, SOLiD) with different principle and divergent features such as run times, yields and read lengths [31] (Table 1).

Advances in NGS have revolutionized the field of microbial ecology. Any NGS study follow some common steps such as sample and metadata collection, DNA extraction, library construction, sequencing and read preprocessing followed by quantitative analysis and functional binning $[32,33]$. Collection of environment sample is the first step in any metagenomic study. But, the problem faced in microbial ecology studies are that no information is available about the amount of required sampling that will comprise entire population in an environment. Usually rarefaction curve, a plot of number of species versus number of individuals sampled, which typically defines the population richness and evenness is used to estimate the fraction of species sequenced.

Another important aspect for any successful metagenomic study is the extraction of high quality DNA from the environmental samples [34]. Environmental samples contain DNA in a variety of packages like free DNA, virus particle, and prokaryotic and eukaryotic cells. These can be suspended in water, bound to a solid matrix like soil, or encased in a biofilm or tissue. So extraction methods must be chosen carefully based on the medium and the DNA population of interest (Susannah Green Tringe) and DNA should come from all the microbial representative present in the sample without any shearing or contamination [35] Although many commercial kits are available for metagenome isolation, it is required to develop our own method to optimize extraction and reducing bias caused by unequal lysis of different members of the soil microbial community [36,37]. Beat beating, sonication, detergents or enzymatic lysis have been used for the isolation purpose. Since some samples contain high humic acid, additional purification is required. Polyphenol compound often co-purified along with the DNA can enzymatically modify the isolated DNA [38]. One strategy may be the use of Skimmed milk which can aid in DNA extraction process from soil [39]. Multiple displacement amplification can be used to increase template DNA for samples with very less amount of DNA $[40,41]$.

Two kind of NGS strategy is applied in microbial community analysis: 1) deep amplicon sequencing and 2) complete metagenome or metatranscriptome analysis. Shotgun sequencing is applied to know the function of the community. The analysis procedure involves assembly (merging overlapping short reads into contigs), binning (grouping reads or contigs into individual genomes and assigning the groups to specific species, subspecies, or genus), functional annotation (for the prediction of CDS, CRISPR, noncoding RNAs) and functional assignment to the predicted protein coding sequences. On the other hand, amplicon sequencing is used for community profiling using marker genes (e.g., 16S rRNA gene) in different ecosystems. Procedure involves denoising (filtered the 'noise' sequences from the raw data), Chimera detection (recombinants which are formed when prematurely terminated fragments reanneal to other template DNA during PCR), OTU clustering (alignment is done by either aligning query sequences against pre-aligned reference sequences (42) or using pairwise and multiple sequence alignments), Taxonomic classification (taxonomic

\begin{tabular}{|c|c|c|c|c|c|c|c|c|c|c|}
\hline $\begin{array}{l}\text { Technology } \\
\text { (company) }\end{array}$ & Amplification & Chemistry & $\begin{array}{l}\text { Sequencing } \\
\text { method }\end{array}$ & \begin{tabular}{|c|} 
Yield \\
(Gb/run)
\end{tabular} & $\begin{array}{l}\text { Highest Average } \\
\text { Read Length }\end{array}$ & Error rate & Output file & $\begin{array}{c}\text { Disadvan- } \\
\text { tage }\end{array}$ & Advantage & Website \\
\hline Illumina & $\begin{array}{l}\text { Bridge amplifi- } \\
\text { cation }\end{array}$ & $\begin{array}{l}\text { Reversible dye } \\
\text { terminator (seq- } \\
\text { by-synthesis) }\end{array}$ & $\begin{array}{l}\text { incorporation of } \\
\text { fluorescent nucleo- } \\
\text { tides }\end{array}$ & $1-60$ & $\begin{array}{c}300 \text { bp (overlap- } \\
\text { ping paired-end } \\
\text { sequencing avail- } \\
\text { able }\end{array}$ & $\geq 0.1$ & $\begin{array}{l}\text { Fastq (Phred } \\
+64 \& 33, \text { II- } \\
\text { lumina }+1.8)\end{array}$ & $\begin{array}{c}\text { Short reads } \\
\text { and long } \\
\text { runtime }\end{array}$ & $\begin{array}{l}\text { High } \\
\text { throughput } \\
\text { and low } \\
\text { cost }\end{array}$ & $\begin{array}{c}\text { www.illumina. } \\
\text { com }\end{array}$ \\
\hline $\begin{array}{l}\text { SOLiD } \\
\text { (Life } \\
\text { Technologies) }\end{array}$ & Emulsion PCR & $\begin{array}{l}\text { Sequencing by } \\
\text { ligation (SBL) }\end{array}$ & $\begin{array}{l}\text { fluorescent short } \\
\text { linkers }\end{array}$ & 3 & $\begin{array}{c}75 \text { bp (paired-end } \\
\text { sequencing avail- } \\
\text { able) }\end{array}$ & $>0.06$ & $\begin{array}{c}\text { Fastq (Phred } \\
+33)\end{array}$ & $\begin{array}{l}\text { Long run- } \\
\text { time }\end{array}$ & $\begin{array}{l}\text { Low error } \\
\text { rate }\end{array}$ & $\begin{array}{l}\text { www.applied- } \\
\text { biosystems. } \\
\text { com }\end{array}$ \\
\hline 454 (Roche) & Emulsion PCR & $\begin{array}{l}\text { Pyrosequencing } \\
\text { (seq-by-synthesis) }\end{array}$ & $\begin{array}{l}\text { incorporation of nor- } \\
\text { mal nucleotides }\end{array}$ & 0.7 & 700 bp & 1 & $\begin{array}{l}\text { SFF, fasta, } \\
\quad \text { fastq }\end{array}$ & $\begin{array}{l}\text { High error } \\
\text { rate in ho- } \\
\text { mopolymer }\end{array}$ & Long read & www.454.com \\
\hline $\begin{array}{l}\text { SMAT (Pacific } \\
\text { Bio) }\end{array}$ & $\begin{array}{c}\text { N/A (single } \\
\text { molecule) }\end{array}$ & $\begin{array}{l}\text { Single Mol- } \\
\text { ecule Real Time } \\
\left(\mathrm{SMRT}^{\mathrm{TM}}\right)\end{array}$ & $\begin{array}{l}\text { incorporation of } \\
\text { fluorescent nucleo- } \\
\text { tides }\end{array}$ & $0.3-0.5$ & $\begin{array}{l}5,000 \text { bp average; } \\
\text { maximum read } \\
\text { length } \sim 22,000 \\
\text { bases }\end{array}$ & 16 & $\begin{array}{c}\text { Fastq (Phred } \\
+33)\end{array}$ & $\begin{array}{l}\text { No PCR } \\
\text { longest } \\
\text { reads }\end{array}$ & High error & $\begin{array}{l}\text { www.paci- } \\
\text { ficbio.com }\end{array}$ \\
\hline $\begin{array}{l}\text { Ion Torrent } \\
\text { (Life } \\
\text { Technology) }\end{array}$ & $\mathrm{N} / \mathrm{A}$ & $\begin{array}{l}\text { Proton detection } \\
\text { (seq-by-synthesis) }\end{array}$ & $\begin{array}{l}\text { measuring } \mathrm{pH} \\
\text { change }\end{array}$ & 1 & $\begin{array}{l}400 \text { bp (bidirec- } \\
\text { tional sequencing } \\
\text { available) }\end{array}$ & 1 & $\begin{array}{c}\text { Fastq (Phred } \\
+33)\end{array}$ & new & Short read & $\begin{array}{l}\text { www.iontor- } \\
\text { rent. com }\end{array}$ \\
\hline
\end{tabular}

Table 1: Summary of the major next-generation sequencing platform. 
Citation: De Mandal S, Panda AK, Bisht SS, Kumar NS (2015) Microbial Ecology in the Era of Next Generation Sequencing. Next Generat Sequenc \& Applic S1: 001. doi:10.4172/2469-9853.S1-001

Page 3 of 6

assignment of OTUs) and Statistical analysis, (alpha and betadiversity analysis, multidimensional scaling and analysis of similarities (ANOSIM), hypothesis testing etc). A flow diagram for the analysis of metagenomic data is shown in Figure 1 and Table 2 represents metagenomics tools available for Microbial Ecology Studies.

\section{Third-generation sequencing}

Third-generation sequencing (SMRT sequencing) is based on the sequencing by synthesis approach and allows the detection of single molecules, but also enables real-time sequencing. The biggest advantage is that it allows 20,000 reads or more, with average read lengths of 5 kilobases. Moreover, it can also directly detect epigenetic modifications such as 4-methylctosine ( $\mathrm{mC}), 5-\mathrm{mC}$ and 6-methyladenine [42].

\section{Application of NGS in microbial ecology}

Analysis of microbial community composition and its function is a

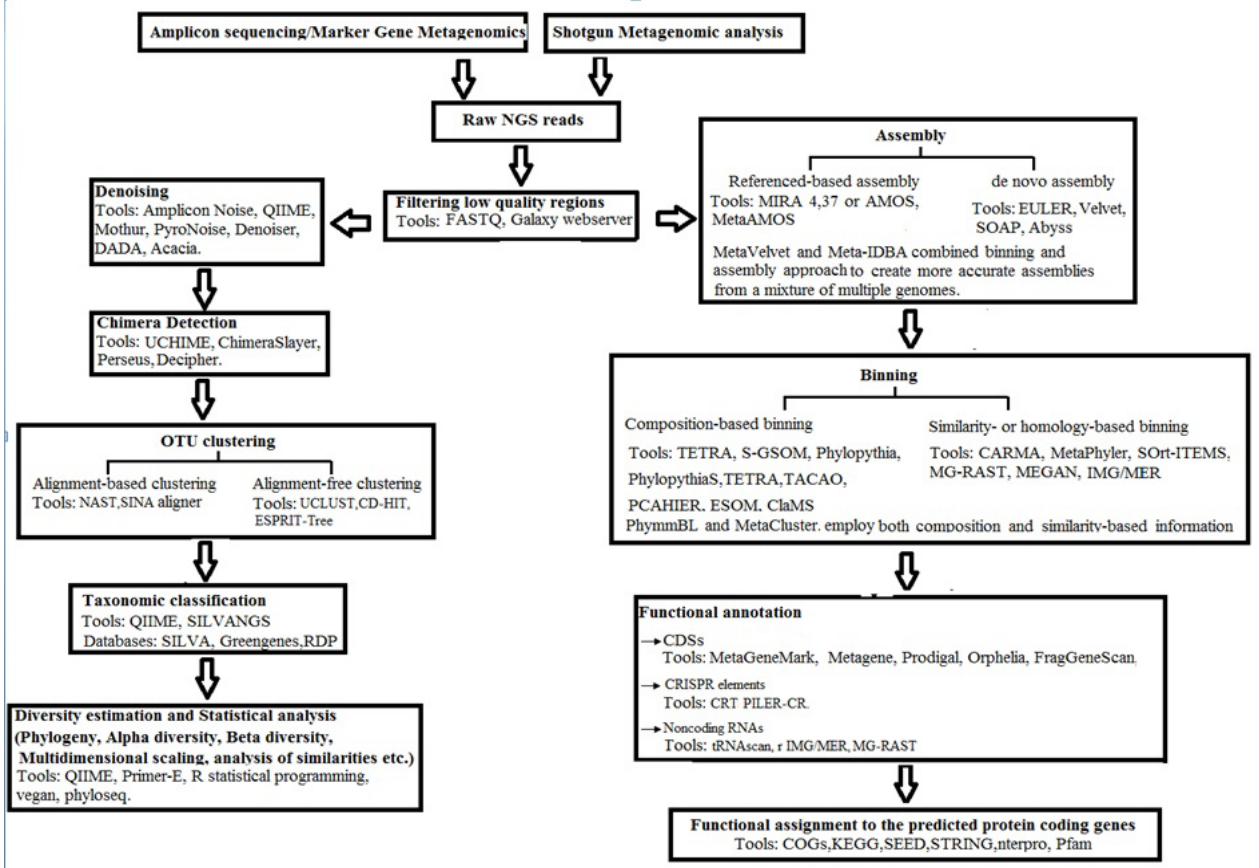

Figure 1: Flow diagram for the analysis of Metagenomics data.

\begin{tabular}{|c|c|}
\hline Metagenomics tools & website \\
\hline \multicolumn{2}{|l|}{ General Software package } \\
\hline STAMP & http://kiwi.cs.dal.ca/Software/STAMP \\
\hline CD-HIT-OUT & http://weizhong-lab.ucsd.edu/cd-hit-otu/ \\
\hline GAAS & http://sourceforge.net/projects/gaas/ \\
\hline Megan & http://www-ab.informatik.unituebingen.de/software/megan/ welcome.html \\
\hline MetaPhIAn & http://huttenhower.sph.harvard.edu/metaphlan \\
\hline MetaSim & http://www-ab.informatik.uni-tuebingen.de/software/metasim \\
\hline Mocat & http://vm-lux.embl.de/ kultima/MOCAT/index.htm \\
\hline Livermore Metagenomics Analysis Toolkit & https://computation-rnd.IInl.gov/lmat \\
\hline Straine & http://www.hsls.pitt.edu/obrc/index.php?page=URL1221230034 \\
\hline \multicolumn{2}{|l|}{ Metagenome assembly } \\
\hline Velvet & http://www.ebi.ac.uk/ zerbino/velvet/ \\
\hline Celera & http://www.cbcb.umd.edu/research/assembly.shtml\#software \\
\hline Metasim & http://ab.inf.uni-tuebingen.de/software/metasim/welcome.html \#Download \\
\hline Euler & http://nbcr.sdsc.edu/euler/ JAZZ \\
\hline \multicolumn{2}{|l|}{ Mapping to reference genome } \\
\hline Bowtie & http://bowtie-bio.sourceforge.net/index.shtml \\
\hline BWA & http://bio-bwa.sourceforge.net/ \\
\hline MAPLE: & http://www.genome.jp/maple-bin/mapleSubmit.cgi?aType=sDirect \\
\hline \multicolumn{2}{|l|}{ Quality analysis } \\
\hline FastQC & http://www.bioinformatics.babraham.ac.uk/projects/download.html\#fastqc \\
\hline Prinseq & http://edwards.sdsu.edu/cgi-bin/prinseq/prinseq.cgi \\
\hline \multicolumn{2}{|l|}{ Gene calling } \\
\hline Genemark. & hmm http://exon.gatech.edu/GeneMark/metagenome/Prediction/ \\
\hline
\end{tabular}




\begin{tabular}{|c|c|}
\hline \multicolumn{2}{|c|}{ Microbial diversity Analysis } \\
\hline MLST & http://www. mlst.net) http://www.mlst.net/ \\
\hline MOTHUR & http://www.mothur.org/ \\
\hline EstimateS & http://viceroy.eeb.uconn.edu/EstimateS/ \\
\hline QIIME & http://qiime.org/install/virtual_box.html \\
\hline PHACCS & http://phaccs.sourceforge.net/ \\
\hline \multicolumn{2}{|l|}{ Binning } \\
\hline TETRA & http://www.megx.net/tetra/index.html \\
\hline Phylopathia & http://cbcsrv.watson.ibm.com/phylopythia.html \\
\hline MEGAN & http://ab.inf.uni-tuebingen.de/software/megan/ \\
\hline CARMA & http://www.cebitec.uni-bielefeld.de/brf/carma/carma.html \\
\hline Phymm & http://www.cbcb.umd.edu/software/phymm/ \\
\hline \multicolumn{2}{|l|}{ Functional Annotation } \\
\hline MEX (Motif Extraction) & http://adios.tau.ac.il/SPMatch/ \\
\hline RAMMCAP & http://weizhong-lab.ucsd.edu/rammcap/cgi-bin/rammcap.cgi \\
\hline \multicolumn{2}{|c|}{ Analysis of quantitative metagenomics data. } \\
\hline FANTOM: & http://www.sysbio.se/Fantom/ \\
\hline \multicolumn{2}{|c|}{ Comparitive Metagenomics } \\
\hline MEGAN & http://metagenomics.anl.gov/ \\
\hline MG-RAST & http://metagenomics.anl.gov \\
\hline Camera & http://camera.calit2.net/ \\
\hline Shotgun FunctionalizeR & http://shotgun.math.chalmers.se/ \\
\hline MetaStats & http://metastats.cbcb.umd.edu/detection.html \\
\hline UniFrac & http://bmf.colorado.edu/unifrac/ \\
\hline Galaxy & https://main.g2.bx.psu.edu/u/aun1/w/metagenomic-analysis \\
\hline MetaMine & http://www.megx.net/metamine/ \\
\hline MetaLook & http://www.megx.net/metalook/index.php \\
\hline IMG/M & http://img.jgi.doe.gov/cgi-bin/m/main.cgi \\
\hline \multicolumn{2}{|c|}{ Online tools for NGS analysis } \\
\hline Parallel Meta & http://www.computationalbioenergy.org/parallel-meta.html \\
\hline SOrt-ITEMS & http://metagenomics.atc.tcs.com/binning/SOrt-ITEMS/ \\
\hline PANGEA & http://www.ohloh.net/p/pangea-plus \\
\hline Genohub: & https://genohub.com/bioinformatics/17/metagenomic-analysis \\
\hline \multicolumn{2}{|c|}{ Additional Metagenome analysis links } \\
\hline EBI Metagenomics: & https://www.ebi.ac.uk/metagenomics \\
\hline MetaPhIAn: & http://huttenhower.sph.harvard.edu/metaphlan \\
\hline Amphora & Net http://pitgroup.org/amphoranet \\
\hline
\end{tabular}

Table 2: Metagenomics tools available for microbial ecology studies

major objective in modern microbial ecology studies. NGS has already been applied in such studies in diverse ecosystem such as caves, forests, hot springs, deserts etc [43-47]. A pyrosequencing based approach revealed that the soil stratification and resource availability can impact the taxonomic and functional diversity of bacterial communities [48]. NGS based studies have proved that the agriculture management system can significantly affect the microbial diversity $[49,50]$. Chhabra et al. [51] identified genes and operons responsible for mineral phosphate solubilization in the barley rhizosphere using pyrosequencing. A NGS based study of soil bacterial communities showed that the conversion of primary Amazonian forest to pasture increases bacterial alphadiversity, but decreases beta diversity resulting in the homogenization of communities across space. This homogenization is driven by the loss of forest soil bacteria with restricted ranges (endemics) and results in a net loss of diversity [52]. Analysis using 227 million Illumina shotgun sequences from forest soil and 246 million from deforested soils revealed that bacterial taxonomic and functional adaptations at the bacterial community level is due to an increase in nutrient availability from slash and burn clearing of Amazon forest [53]. Analysis of 62081 pyrosequencing reads from 10 soil samples revealed that bacterial diversity and soil physicochemical properties did not show consistent changes along the elevation gradients in southwestern highlands of Saudi Arabia [54]. An NGS study carried out in temperate deciduous forest of Northeast Ohio, USA found that the vernal pool microbial communities may rely on their metabolic plasticity for growth and survival during limited resources [55]. Analysis of NGS reads shown that microbial functional activity increased throughout decomposition in spring, summer and winter, while it decreased in autumn in a Midwest temperate forest in Morris Bean Reserve of Greene County, Ohio, USA [56]. Pyrosequencing of V3-V4 regions described the bacterioplankton communities in a coastal Antarctic lake which is under long-term environmental change [57]. Fierer et al. [47] used Illumina shotgun sequencing in different ecosystem and found that desert microbial communities had high relative abundance of genes associated with osmoregulation and dormancy, whereas genes linked with nutrient cycling and catabolism of plant-derived organic compounds was less. This study also revealed that abiotic factors are more important in harboring the desert microbial communities. Another shotgun study detected identification of genes related to phytic acid utilization [58]. Analysis of total of 1,294,216 raw 16S rRNAV6 sequences revealed that Actinobacteria, Acidobacteria, Nitrospirae, and Verrucomicrobia were abundant in nutrient-rich inner mangrove sediments, while Proteobacteria and Deferribacterias were high in outer mangrove sediments [59]. Based on pyrosequencing of the V2- 
V3 $16 \mathrm{~S}$ rRNA gene regions, Nacke et al. [60] found that soil bacterial community composition and diversity of the six analyzed management types showed significant differences between the land use patterns in grassland and forest ecosystems and more over bacterial community structure was largely driven by tree species and soil $\mathrm{pH}$.

NGS technologies are improving day by day with more accuracy and longer sequence reads which are applied in many microbial ecology studies. Due to the continuous decrease in NGS cost, a huge number of environmental samples has been sequenced to solve research problems in microbial ecology. This paper will be helpful in understanding the basics of next generation sequencing as well as for designing new metagenomics projects. Future research with the help of NGS technologies will further unzip the unseen microbial diversity and its function useful in solving ecological problems.

\section{Acknowledgements}

The authors thank DBT, New Delhi for supporting Bioinformatics Infrastructure Facility, Mizoram University which has provided the essential facilities to carry out the work. The first author is thankful to DBT-State Biotech Hub, Mizoram University for the fellowship.

\section{References}

1. Nichols DS, Sanderson K, Buia A, Kamp J, Halloway P et al. (2002) Bioprospecting and biotechnology in Antarctica. In: Jabour-Green J, Haward M (eds). The Antarctic: Past, Present and Future. Antarctic CRC. Res. Report, Hobart, 85-103.

2. Torsvik VL, Øvreås L (2011) DNA Reassociation Yields Broad-Scale Information on Metagenome Complexity and Microbial Diversity. In: Handbook of Molecular Microbial Ecology I. John Wiley \& Sons, Inc., 3-16.

3. Handelsman J (2004) Metagenomics: application of genomics to uncultured microorganisms. Microbiol Mol Biol Rev 68: 669-685.

4. Kimura N (2006) Metagenomics: Access to unculturable microbes in the environment. Microb Environ 21: 201-215.

5. Tringe SG and Rubin EM (2005) Metagenomics: DNA sequencing of environmental samples. Nat Rev Genet 6: 805-814.

6. Rappe MS, Connon SA, Vergin KL, Giovannoni SJ (2002) Cultivation of the ubiquitous SAR11 marine bacterioplankton clade. Nature 418: 630-633.

7. Sait M, Hugenholtz P, Janssen PH (2002) Cultivation of globally distributed soil bacteria from phylogenetic lineages previously only detected in cultivation independent surveys. Environ Microbiol 4: 654-666.

8. Zwirglmaier K, Ludwig W, Schleifer KH (2004) Recognition of individual genes in a single bacterial cell by fluorescence in situ hybridization-RING-FISH. Mol Microbiol 51: 89-96.

9. Voget S, Steele HL, Streit WR (2006) Characterization of a metagenomederived halotolerant cellulose. J Biotechnol 126: 26-36.

10. Waschkowitz T, Rockstroh S, Daniel R (2009) Isolation and characterization of metalloproteases with a novel domain structure by construction and screening of metagenomic libraries. Appl Environ Microbiol 75: 2506-2516.

11. Stein JL, Marsh TL, Wu KY, Shizuya H, DeLong EF (1996) Characterization of uncultivated prokaryotes: isolation and analysis of a 40-kilobase- pair genome fragment from a planktonic marine archeon J Bacteriol 178: 591-599.

12. Uchiyama T, Abe T, Ikemura T, Watanable K (2005) Substrate induced geneexpression screening of environmental metagenome libraries for isolation of catabolic genes. Nat Biotechnol 23: 88-93.

13. Heath C, Hu XP, Cary SC, Cowan D (2009) Identification of a novel alkaliphilic esterase active at low temperatures by screening a metagenomic library from Antarctic desert soil. Appl. Environ. Microbiol 75: 4657-4659.

14. Pace N, Stahl D, Lane D, Olsen G (1985) Analysing natural microbia populations by rRNA sequences. ASM News 51: 4-12.

15. Elend C, Schmeisser C, Leggewie C, Babiak P, Carballeira JD, et al. (2006) Isolation and biochemical characterization of two novel metagenome derived esterases. Appl Environ Microbiol 72: 3637-3645.
16. Vakhlu J, Kour A, Johri B (2008) Metagenomics: future of microbial gene mining. Indian J Microbiol 48: 202-215.

17. Pace NR (1997) A molecular view of microbial diversity and the biosphere. Science 276: 734-740.

18. Birtel J, Walser JC, Pichon S, Bürgmann H, Matthews B (2015) Estimating Bacterial Diversity for Ecological Studies: Methods, Metrics, and Assumptions. PLoS ONE 10- e0125356.

19. Liu Z, DeSantis TZ, Andersen GL, Knight R (2008) Accurate taxonomy assignments from 16S rRNA sequences produced by highly paralle pyrosequencers. Nucleic Acids Res 36: e120.

20. Huse SM, Dethlefsen L, Huber JA, Mark Welch D, Welch DM, et al. (2008) Exploring microbial diversity and taxonomy using SSU rRNA hypervariable tag sequencing. PLoS Genet 4: e1000255.

21. Wang Q, Garrity GM, Tiedje JM, Cole JR (2007) Naive Bayesian classifier fo rapid assignment of rRNA sequences into the new bacterial taxonomy. Applied and Environment Microbiology 73: 5261-5267.

22. Kumar PS, Brooker MR, Dowd SE, Camerlengo T (2011) Target region selection is a critical determinant of community fingerprints generated by $16 \mathrm{~S}$ Pyrosequencing. PLoS One 6: e20956.

23. Nikolaki S, Tsiamis G (2013) Microbial Diversity in the Era of Omic Technologies BioMed Research International 2013: 1-15.

24. Muyzer G, de Waal EC, Uitterlinden AG (1993) Profiling of complex microbia populations by denaturing gradient gel electrophoresis analysis of polymerase chain reaction amplified genes encoding for $16 \mathrm{~S}$ rRNA. Appl Environ Microbio 59: $695-700$

25. Cancilla MR, Powell IB, Hillier AJ, Davidson BE (1992) Rapid genomic fingerprinting of Lactococcus lactis strains by arbitrarily primed polymerase chain-reaction with P-32 and fluorescent labels. Appl Environ Microbiol 58 1772-1775.

26. Moyer CL, Dobbs FC, Karl DM (1995) Phylogenetic diversity of the bacteria community from a microbial mat at an active, hydrothermal vent system, Loih Seamount, Hawaii. Appl Environ Microbiol 61: 1555-1562.

27. Sheffield VC, Beck JS, Stone EM, Myers RM (1992) A simple and efficient method for attachment of a 40-base pair, GC-rich sequence to PCR-amplified DNA. BioTechniques 12: 386-387.

28. Rastogi G, Sani R (2011) Molecular Techniques to Assess Microbial Community Structure, Function, and Dynamics in the Environment. In: Springer New York $29-57$

29. Pop M, Salzberg SL (2008) Bioinformatics challenges of new sequencing technology. Trends Genet 24: 142-149.

30. Kircher M, Kelso J (2010) High-throughput DNA sequencing: Concepts and limitations. Bioessays 32: 524-536.

31. Quail MA, Smith M, Coupland P et al. (2012) A tale of three next generation sequencing platforms: comparison of Ion Torrent, Pacific Biosciences and Illumina MiSeq sequencers. BMC Genomics 13: 341

32. Metzker ML (2010) Sequencing technologies-the next generation. Nat Rev Genet 11: 31-46.

33. Richter DC, Ott F, Auch AF, Schmid R, Huson DH (2008) MetaSim-A Sequencing Simulator for Genomics and Metagenomics. PLoS ONE 3: e3373.

34. Kennedy J, Marchesi, JR (2007) Metagenomic approach to exploit the biotechnological potential of the microbial consortia of marine sponges. App Microbiol Biotechnol 75: 11-20.

35. Schmeisser C, Helen S, Wolfgang RS (2007) Metagenomics, biotechnology with non culturable microbes. Appl Microbiol Biotechnol 75: 955-962.

36. Krsek M, Wellington EM (1999) Comparison of different methods for the isolation and purification of total community DNA from soil. J Microbiol Methods 39: $287-294$.

37. Miller DN, Bryant JE, Madsen EL, Ghiorse WC (1999) Evaluation and optimization of DNA extraction and purification procedure for soil and sediment samples. Appl Environ Microbiol 65: 4715-4724.

38. Tsai YL, Olson BH (1992) Rapid method for separation of bacterial DNA from humic substances in sediments for polymerase chain reaction. Appl Environ Microbiol 58: 2292-2295. 
39. Hoshino YT, Matsumoto N (2004) An improved DNA extraction method using skim milk from soils that strongly adsorb DNA. Microbes Environ 19: 13-19.

40. Eisen JA (2007) Environmental shotgun sequencing: its potential and challenges for studying the hidden world of microbes. PLoS Biol 5: e82.

41. Lasken RS (2009) Genomic DNA amplification by the multiple displacement amplification (MDA) method. Biochem Soc Trans 37: 450-453.

42. Murray IA, Clark TA, Morgan RD, Boitano M, Anton BP, et al. (2012) The methylomes of six bacteria Nucleic Acids Res 40: 11450-11462.

43. De Mandal S, Sanga Z, Senthil Kumar N (2015) Metagenome sequencing reveals Rhodococcus dominance in Farpuk Cave, Mizoram, India, an Eastern Himalayan biodiversity hot spot region. Genome Announc 3: e00610-e00615.

44. De Mandal S, Panda AK, Lalnunmawii E, Bisht SS, Senthil Kumar N (2015) Illumina-based analysis of bacterial community in Khuangcherapuk cave of Mizoram, Northeast India. Genomics Data 5: 13-14.

45. De Mandal S, Sanga Z, Lalremsanga HT, Senthil Kumar N (2015) Bacterial diversity of Murlen National Park located in Indo-Burman Biodiversity hotspot region: A metagenomic approach. Genomics Data 5: 25-26.

46. Panda AK, Bisht SS, Senthil Kumar N, De Mandal S (2015) Investigations on microbial diversity of Jakrem hot spring, Meghalaya, India using cultivation independent approach. Genomics Data 4: 156-157.

47. Fierer N, Leff JW, Adams BJ, Nielsen UN, Scott TB, et al. (2012) Cross-biome metagenomic analyses of soil microbial communities and their functional attributes. PNAS 109: 21390-21395.

48. Uroz S, loannidis P, Lengelle J, Cébron A, Morin E, Buée M, et al. (2013) Functional Assays and Metagenomic Analyses Reveals Differences between the Microbial Communities Inhabiting the Soil Horizons of a Norway Spruce Plantation. PLoS ONE 8: e55929.

49. Roesch LF, Fulthorpe RR, Riva A, Casella G, Hadwin AK, et al. (2007) Pyrosequencing enumerates and contrasts soil microbial diversity. ISME Journal 1: 283-290.

50. Acosta-Martínez V, Dowd S, Sun Y, Allen V (2008) Tag-encoded pyrosequencing analysis of bacterial diversity in a single soil type as affected by management and land use. Soil Biology and Biochemistry 40: 2762-2770.

51. Chhabra S, Brazil D, Morrissey J, Burke JI, O'Gara F, et al. (2013) Characterization of mineral phosphate solubilization traits from a barley rhizosphere soil functional metagenome. Microbiologyopen 2: 717-724.

52. Rodrigues JLM, Pellizari VH, Mueller R, Baek K, Jesus EC, et al. (2013) Conversion of the Amazon rainforest to agriculture results in biotic homogenization of soil bacterial communities. Proc Natl Acad Sci USA 110 988-993.

53. Navarrete AA, Tsai SM, Mendes LW, Faust K, de Hollander M, et al. (2015) Soil microbiome responses to the short-term effects of Amazonian deforestation. Mol Ecol 24: 2433-2448.

54. Yasir M, Azhar E, Khan I, Bibi F, Baabdullah, et al. (2015) Composition of soil microbiome along elevation gradients in southwestern highlands of Saudi Arabia. BMC Microbiol 15: 65

55. Pechal JL, Crippen TL, Tarone AM, Lewis AJ, Tomberlin JK, et al. (2013) Microbial Community Functional Change during Vertebrate Carrion Decomposition. PLoS ONE 8: e79035.

56. Carrino-Kyker S, Smemo K, Burke D (2013) Shotgun metagenomic analysis of metabolic diversity and microbial community structure in experimental vernal pools subjected to nitrate pulse. BMC Microbiol 13: 78.

57. Logares R, Lindström ES, Langenheder S, Logue JB, Paterson $\mathrm{H}$ et al., (2013) Biogeography of bacterial communities exposed to progressive long-term environmental change. The ISME Journal 7: 937-948.

58. Unno Y, Shinano T (2013) Metagenomic analysis of the rhizosphere soil microbiome with respect to phytic acid utilization. Microbes Environ 28: 120-127.

59. Jiang XT, Peng X, Deng GH, Sheng HF, Wang Y, et al. (2013) Illumina sequencing of $16 \mathrm{~S}$ rRNA tag revealed spatial variations of bacterial communities in a mangrove wetland. Microb Ecol 66: 96-104.

60. Nacke H, Thürmer A, Wollherr A, Will C, Hodac L, et al. (2011) Pyrosequencingbased assessment of bacterial community structure along different management types in german forest and grassland soils. PLoS ONE 6: e17.
This article was originally published in a special issue, Sequencing Technologies handled by Editor(s). Dr. Jianping Wang, University of Florida, USA. 